\title{
Sistem Pengaman Kunci Kontak Sepeda Motor Melalui Android Berbasis NodeMCU ESP8266
}

\section{The Motorcycle Ignition Key Security System Via Android Based On NodeMCU ESP8266}

\author{
Fikra Titan Syifa ${ }^{1, *}$, Gilang Prayoga ${ }^{2}$, Muntaqo Alfin Amanaf ${ }^{3}$ \\ ${ }^{1,2}$ Prodi S1 Teknik Telekomunikasi, ${ }^{3}$ Prodi D3 Teknik Telekomunikasi, \\ Fakultas Teknik Telekomunikasi dan Elektro, Institut Teknologi Telkom Purwokerto \\ Jln. D.I. Panjaitan no.128 Purwokerto, 53147 Jawa Tengah \\ 1,*Penulis korespondensi: fikra@ittelkom-pwt.ac.id, \\ 216201079@ittelkom-pwt.ac.id, ${ }^{3}$ muntaqo@ittelkom-pwt.ac.id
}

Received on 02-12-2019, accepted on 30-12-2020, published on 30-12-2020

Abstrak

Pada penelitian ini telah dikembangkan mengenai sistem pengaman kunci kontak pada sepeda motor secara nirkabel untuk mencegah kasus pencurian. Modul atau perangkat nirkabel menggunakan sistem minimum berupa NodeMCU ESP8266 yang terhubung pada perangkat smartphone milik pengguna. Terdapat dua buah sensor getaran SW420 yang diletakkan pada titik-titik tertentu pada rangka (chasis) sepeda motor. Secara keseluruhan sistem pengiriman data terdekat dengan jarak 1 meter dari NodeMCU menuju perangkat android user membutuhkan RTT (round trip time) sebesar 8.37 ms dan throughput sebesar 3192 bps. Kemudian jarak terjauh yang dapat diukur sejauh 28 meter dengan RTT sebesar 9,3 ms dan memiliki throughput 3400 bps. Proses pengiriman data dilakukan secara satu arah. Parameter yang diukur yaitu jarak, throughput, dan RTT.

Kata kunci: Nirkabel, NodeMCU, Perangkat android, Sistem pengaman motor, Throughput.

\section{Abstract}

In this research, a wireless ignition lock safety system has been developed to prevent theft cases. The wireless module or device uses a minimum NodeMCU ESP8266, connected to the user's smartphone device. In addition, two SW420 vibration sensors are placed at specific points on the motorcycle chassis. Overall, the closest data transmission system with a distance of 1 meter from the NodeMCU to the user's android device requires an RTT (round trip time) of $8.37 \mathrm{~ms}$ and a throughput of $3192 \mathrm{bps}$. Then the farthest distance that can be measured is 28 meters with an RTT of $9.3 \mathrm{~ms}$ and has a throughput of $3400 \mathrm{bps}$. The process of sending data is done in one direction. Parameters measured are distance, throughput, and RTT.

Keywords: Android device, Motor safety system, NodeMCU, Throughput, Wireless.

\section{Pendahuluan}

Perkembangan teknologi telekomunikasi yang cepat dan sistem telekomunikasi yang canggih serta modern memiliki pengaruh positif pada kehidupan masyarakat. Namun, hal tersebut juga berpengaruh pada gaya hidup yang serba instan. Smartphone atau gawai saat ini bagaikan kebutuhan primer bagi masyarakat bawah hingga atas, yang hampir setiap orang memiliki satu buah smartphone atau gawai dari anak-anak hingga orang dewasa [1]. Selain itu, bidang transportasi roda dua khususnya sepeda motor juga berperan dalam menunjang kemajuan teknologi. Sepeda motor membantu manusia dalam mobilitas sehari-hari di masyarakat. Unsur kepraktisan juga mempunyai nilai lebih dalam hal pengeluaran. 
Maraknya kasus pencurian sepeda motor dengan cara merusak kunci kontak sepeda motor menjadi latar belakang penelitian ini. Perancangan sistem keamanan dan kunci kontak sepeda motor melalui platform android pada smartphone diharapkan akan membantu dalam rangka mengamankan kendaraan sepeda motor untuk meminimalisir pencurian serta menjadikan gawai sebagai pengganti kunci kontak pada sepeda motor yang dapat menyalakan mesin sepeda motor dengan meletakkan mikropengendali NodeMCU ESP8266 melalui jaringan secara wireless (nirkabel) dengan sebuah aplikasi khusus yang dapat mengendalikan sistem keamanan pada sepeda motor.

\section{TINJAUAN PUStaka}

\section{A. Perangkat Sistem Minimum NodeMCU ESP8266}

Pada penelitian ini menggunakan perangkat atau modul WiFi Node ESP8266. NodeMCU adalah sebuah platform IoT yang bersifat opensource. Terdiri dari perangkat keras berupa System On Chip ESP8266 dari ESP8266 buatan Espressif System, juga firmware yang digunakan, yang menggunakan bahasa pemrograman scripting Lua.

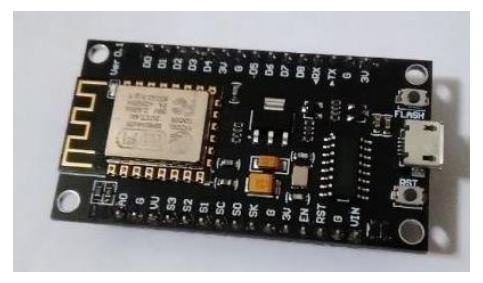

Gambar 1. NodeMCU ESP8266

Istilah NodeMCU secara default sebenarnya mengacu pada firmware yang digunakan daripada perangkat keras development kit. NodeMCU bisa dianalogikan sebagai board arduino-nya ESP8266. Dalam memprogram ESP8266 sedikit merepotkan karena diperlukan beberapa teknik wiring serta tambahan modul USB to serial untuk mengunduh program. Namun NodeMCU telah me-package ESP8266 ke dalam sebuah board yang kompak dengan berbagai fitur layaknya mikrokontroler plus kapabilitas akses terhadap Wi-Fi juga chip komunikasi USB to serial. Sehingga untuk memprogramnya hanya diperlukan ekstensi kabel data USB persis sama seperti yang digunakan sebagai kabel data dan kabel charging smartphone Android. ESP8266 menggunakan standar tegangan JEDEC (tegangan 3,3 volt) untuk bisa berfungsi. Tidak seperti mikrokontroler AVR dan sebagian besar board Arduino yang memiliki tegangan TTL 5 volt. Meskipun begitu, NodeMCU masih bisa terhubung dengan 5 volt melalui port micro USB atau pin Vin yang terdapat pada barisan pin di board-nya. Namun karena semua pin pada ESP8266 tidak toleran terhadap masukan 5 volt. Maka jangan pernah mencoba untuk menghubungkan langsung catu daya dengan tegangan TTL jika tidak ingin merusak board NodeMCU. Namun dapat digunakan Level Logic Converter untuk mengubah tegangan ke nilai aman 3,3 volt.

\section{B. Perangkat Android}

Android merupakan sebuah sistem operasi untuk perangkat mobile berbasis linux yang mencakup sistem operasi, minddleware dan aplikasi. Android sangat terbuka bagi pengembang atau menciptakan aplikasi buatan sendiri melalui platfromnya. Android berasal dari Android Inc. yang merupakan pembuat piranti lunak untuk ponsel yang baru berdiri yang kemudian dibeli oleh Google Inc. yang kemudian melakukan perilisan perdana pada tahun 2007 bersama dukungan dari Open Handset Alliance.

\section{Relay DP-DT (Dual Pole-Dual Throw)}

Relay merupakan komponen elektronika berupa saklar atau switch elektrik yang dioperasikan secara listrik dan terdiri dari 2 bagian utama yaitu Elektromagnet (coil) dan mekanikal (seperangkat kontak Saklar/Switch). Komponen elektronika ini menggunakan prinsip elektromagnetik untuk menggerakan saklar sehingga dengan arus listrik yang kecil (low power) dapat menghantarkan listrik yang bertegangan lebih tinggi. Ketika kumparan coil di berikan arus listrik, maka akan timbul gaya elektromagnet sehingga 
akan menarik Armature berpindah posisi yang awalnya NC (tertutup) ke posisi NO (terbuka) sehingga menjadi saklar yang dapat menghantarkan arus listrik di posisi NO. Posisi Armature yang tadinya dalam kondisi close akan menjadi open atau terhubung. Armature akan kembali keposisi close saat tidak dialiri listrik. Coil yang digunakan untuk menarik Contact Point ke posisi close umunnya hanyak membutuhkan arus listrik yang relatif kecil [2].

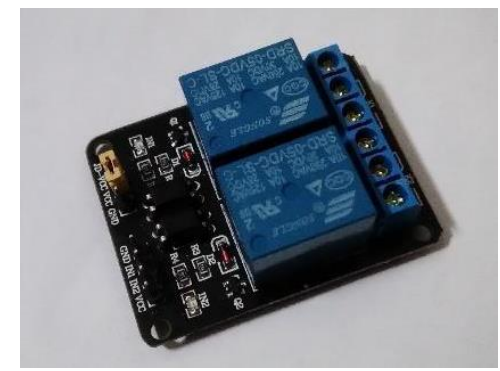

Gambar 2. Relay DP-DT

\section{Regulator IC LM7805}

Sumber tegangan di dalam sebuah rangkaian elektronika sering kali mengalami fluktuasi, sehingga menyebabkan tegangan keluaran bernilai tidak tetap pula. Sebuah IC regulator tegangan membantu menjaga agar tegangan keluaran selalu pada nilai konstan. Salah satu IC regulator yang umum digunakan untuk standar tegangan TTL adalah 7805, yang merupakan anggota dari seri regulator tegangan tetap 78xx. Tanda xx mengindikasikan tegangan keluaran yang disediakan. IC7805 menyediakan catu daya teregulasi dengan beda potensial 5 volt[3].

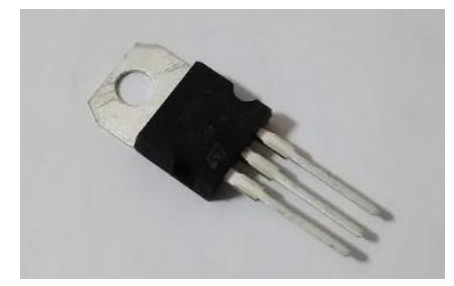

Gambar 3. IC Regulator LM7805

\section{E. Sensor SW-420}

Pada prototipe yang dibuat terdapat sebuah sistem pengaman yang digunakan sebagai pengaman tambahan sepeda motor, dimana pengaman tambahan mengandalakan sebuah masukan berupa sinyal getaran yang didapatkan oleh sepeda motor yang nantinya akan digunkan oleh sistem pengamanan untuk sebagai dasar informasi sistem dalam proses membunyikan klakson yang merupakan hasil dari keluaran sistem pengaman tambahan pada sepeda motor.

Sensor getaran dalam prototipe menggunakan modul SW420 dengan tegangan kerja 3,3 sampai 5 V seperti pada gambar 4. Jika getaran lemah atau tidak terjadi getaran maka nilai logika outputnya rendah, sebaliknya jika terjadi getaran dengan frekeunsi tertentu maka nilai logika output sensor tersebut tinggi[4].

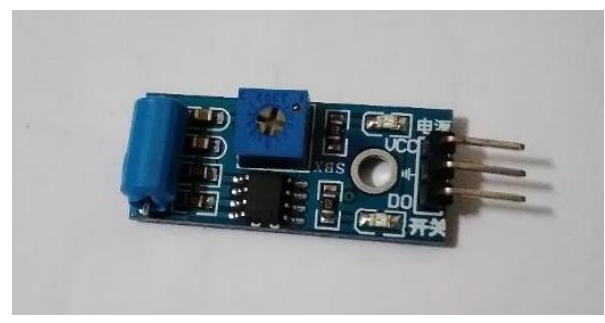

Gambar 4. Sensor Getar SW420 


\section{F. App Inventor}

App Inventor merupakan aplikasi berbasis web open source yang awalnya dikembangkan oleh Google, dan saat ini dikelola oleh Massachusetts Institute of Technology (MIT). App Inventor memungkinkan pengguna baru untuk memprogram komputer untuk menciptakan aplikasi perangkat lunak bagi sistem operasi Android. App Inventor ini menggunakan antarmuka grafis, serupa dengan antarmuka pengguna pada Scratch, yang memungkinkan pengguna men-drag-and-drop objek visual untuk menciptakan aplikasi yang bisa dijalankan pada perangkat Android. Begitupun dengan coding, tidak perlu menulis kode program yang cukup panjang, dapat dengan men-drag-and-drop seperti menyusun blok[5].

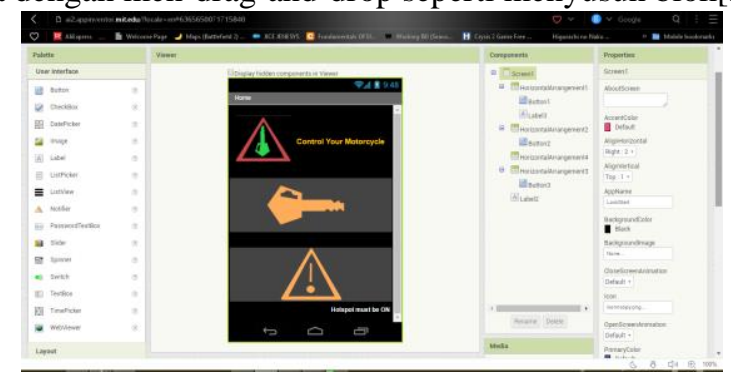

Gambar 5. Coding Secara Online App Inventor

\section{G. Arduino IDE}

IDE merupakan Integrated Developtment Environment, atau sebuah piranti yang terintegrasi digunakan untuk melakukan pengembangan. Disebut sebagai lingkungan karena melalui software inilah Arduino dilakukan pemrograman untuk melakukan fungsi-fungsi yang dibenamkan melalui sintaks pemrograman. Arduino menggunakan bahasa pemrograman sendiri yang menyerupai bahasa C. Bahasa pemrograman Arduino (Sketch) sudah dilakukan perubahan untuk memudahkan pemula dalam melakukan pemrograman dari bahasa aslinya. Sebelum dijual ke pasaran, IC mikrokontroler Arduino telah ditanamkan suatu program bernama Bootlader yang berfungsi sebagai penengah antara compiler Arduino dengan mikrokontroler. Arduino IDE dibuat dari bahasa pemrograman JAVA. Arduino IDE juga dilengkapi dengan library C/C++ yang biasa disebut wiring yang membuat operasi input dan output menjadi lebih mudah. Arduino IDE ini dikembangkan dari software Processing yang dirombak menjadi Arduino IDE khusus untuk pemrograman dengan Arduino[6].

\section{Perancangan Sistem}

Pada proses perancangan sistem dilakukan beberapa tahap yang harus dilakukan dalam membuat sistem yang akan dibuat yang mencakup cara kerja sistem, proses persiapan untuk membuat sistem, proses perakitan hingga proses pengujian sistem sehingga sistem yang dibuat dapat berjalan sesuai dengan rencana. Sebelum mempersiapkan sistem yang akan dibuat adalah diagram alir atau flowchart, pada gambar 6 yang menjelaskan alur kerja sistem yang akan dibuat. 


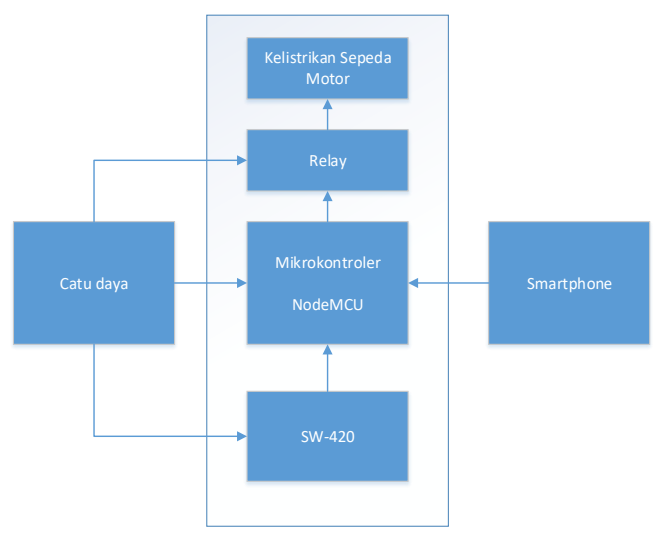

Gambar 6. Blok Diagram Sistem Minimum NodeMCU

Pada diagram blok seperti pada gambar 6 dapat diketahui bahwa catu daya tegangan pada rangkaian pengendali yang berisi NodeMCU, relay serta sensor SW-420 terhubung ke rangkaian kelistrikan pada sepeda motor dengan perintah yang berasal dari smartphone sebagai pusat pengendali mikrokontroler

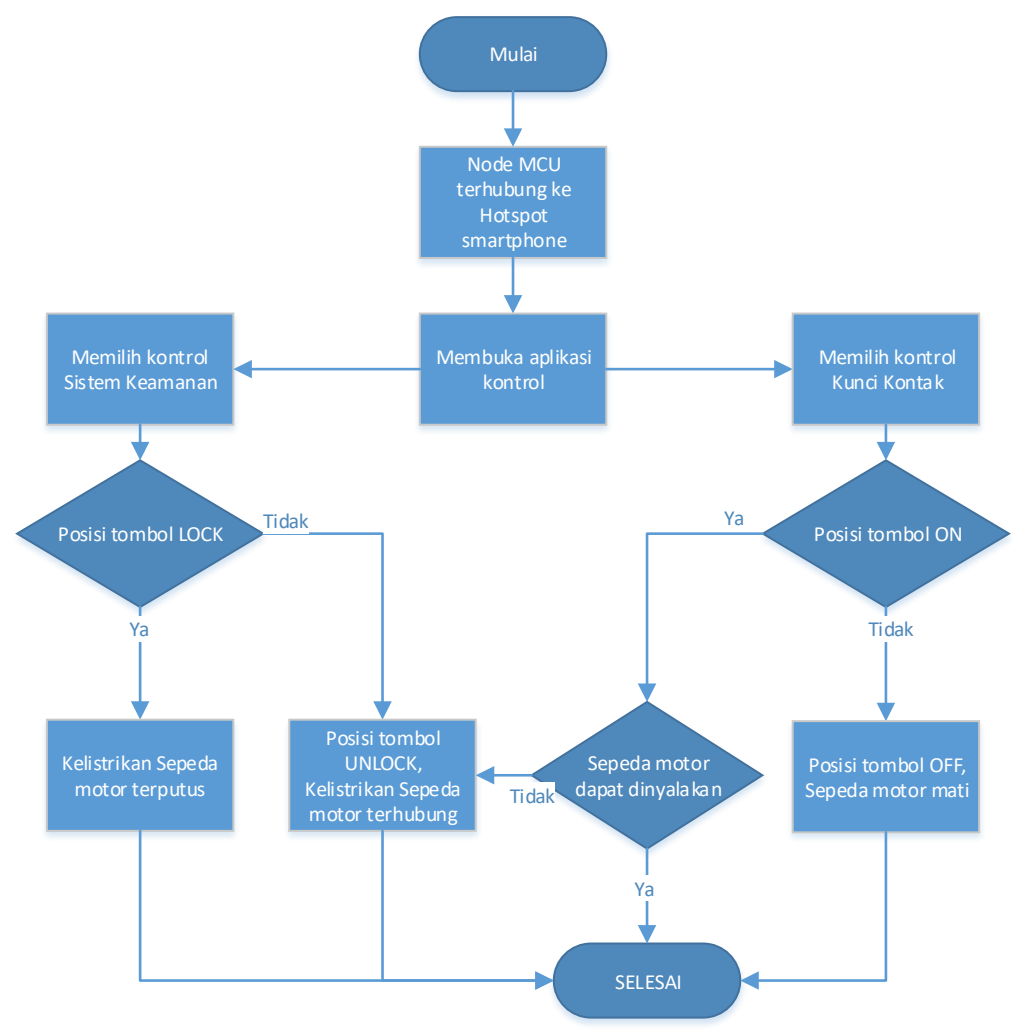

Gambar 7. Alur Diagram Algoritma Sistem Pengendali

Untuk memulai sistem dimulai dengan menyalakan hotspot pada smartphone. Kemudian membuka aplikasi untuk memulai pengendalian rangkaian. Aplikasi dapat mengendalikan rangkaian pengamanan pada sepeda motor yang akan memutuskan kelistrikan. Sedangkan pada fungsi kedua sebagai pengganti kunci kontak. Berikutnya terdapat tombol yang berfungsi sebagai tombol "starter". Seperti pada gambar 7, digambarkan bahwa untuk dapat menyalakan kunci kontak, posisi dari sistem keamanan harus dalam keadaan tidak aktif.

Dalam membuat perangkat pengendali yang akan dipasang pada sepeda motor, dibangun dalam sebuah kotak hitam dengan ukuran $12 \mathrm{~cm}$ x $8 \mathrm{~cm}$ x $5 \mathrm{~cm}$, sehingga tidak terlalu memakan ruang pada bagasi sepeda motor sebagai tempat untuk meletakan pengendali saat dipasang. 


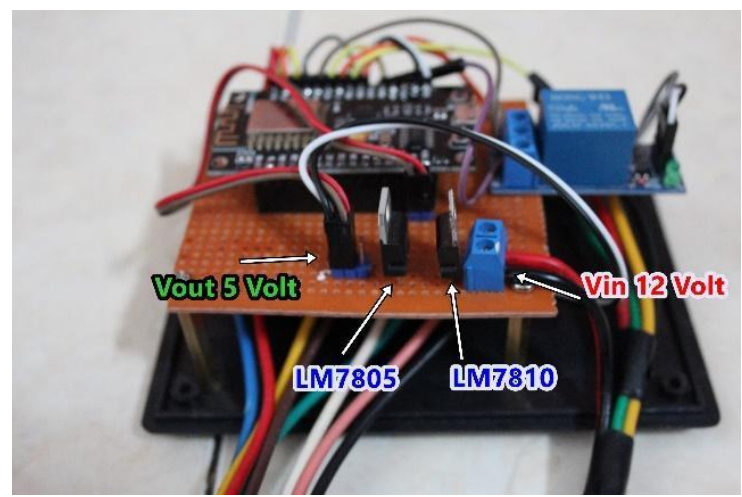

Gambar 8. Shield Rangkaian Sistem Minimum

Didalam kotak hitam pengendali memiliki dua lapisan komponen yang menyatu dalam papan PCB rangkaian. Pada lapisan atas seperti gambar 8 yang berisi NodeMCU, sebuah relay dan rangkaian catu daya yang berisi IC LM 7810 dan LM 7805 sebagai sumber tegangan untuk rangkaian pengendali dalam kotak.

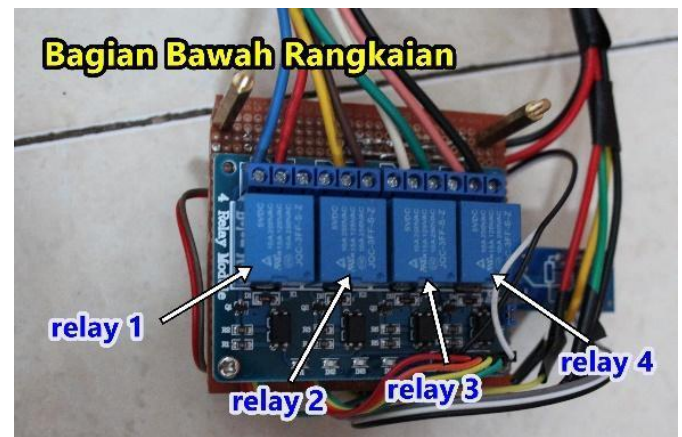

Gambar 9. Rangkaian Relay SPDT

Kemudian pada bagian bawah rangkaian berisi relay dengan 4 kanal yang terkoneksi dengan kabel menuju port pengendali seperti pada gambar 9. Fungsi dari masing-masing relay yaitu sebagai pemutus rangkaian kelistrikan.

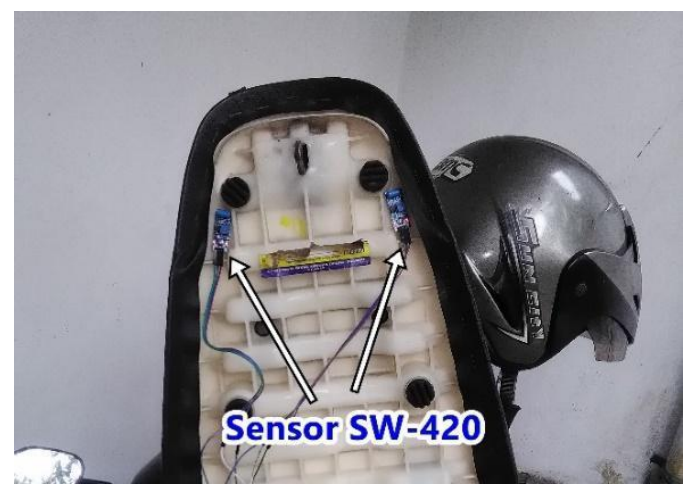

Gambar 10. Letak Sensor Getar SW-420

Pada sistem pengendali yang dibuat, digunakan dua buah sensor SW-420 yang akan digunakan untuk mendeteksi getaran yang dialami oleh sepeda motor sebagai tolok ukur sistem untuk mengetahui adanya resiko pencurian dan sistem minimum NodeMCU akan secara otomatis menyalakan buzzer yang terpasang sebagai tindak lanjut atas data yang diterima dari sensor getar. 


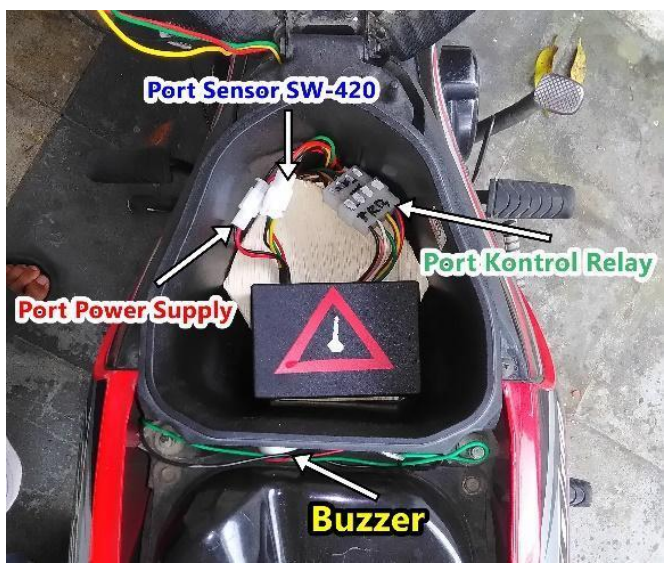

Gambar 11. Pemasangan Instalasi Rangkaian

Setelah rangkaian pengendali dalam kotak hitam selesai dibangun, maka sistem pengendali dalam digunakan dengan menghubungkan setiap port yang telah disediakan di sepeda motor sesuai dengan kebutuhan seperti pada gambar 11, sehingga sistem pengaman dan kunci kontak sepeda motor dapat berjalan sesuai rancangan.

\section{A. Perancangan Perangkat Lunak}

Dalam proses perancangan aplikasi pengendali sistem, digunakan layanan pembuat aplikasi gratis berbasis web yaitu App Inventor, dalam membuatnya diperlukan beberapa tahap pembuatan.

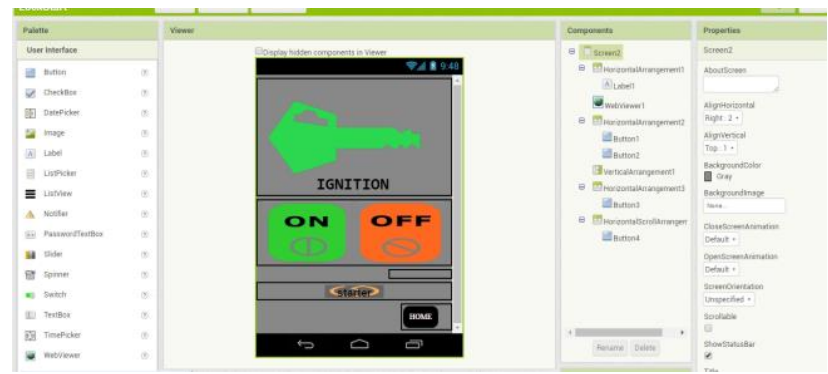

Gambar 12. Perancangan APK Perangkat Android

Tahap awal,membuat tampilan antarmuka yang diinginkan seperti gambar 12, dimana lapisan layar yang akan digunakan untuk melakukan kontrol kunci kontak sepeda motor, pada gambar 12 terdapat 4 buah tombok yang masing-masing berfungsi untuk tombol starter, menghidupkan dan mematikan kunci kontak sepeda motor, kemudian tombol Home pada pojok kanan bawah layar.

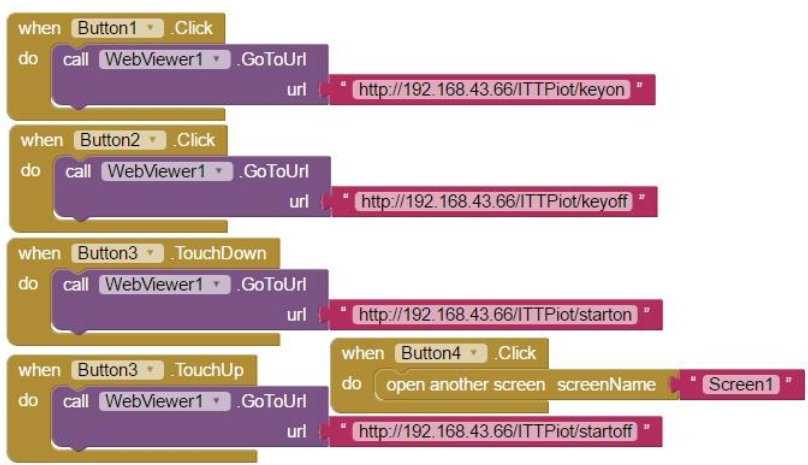

Gambar 13. Susun Blok Emulator AppInventor 
Setelah selesai mengatur tampikan aplikasi yang digunakan, dilanjutkan dengan tahap pembuatan blok pemrograman, dimana tahap ini akan menjalankan perintah yang akan diterima dan tahapan apa yang harus dilakukan dengan bantuan puzzle program. Pada proses pemrograman ini tidak menggunakan bahasa permrograman yang lain. Pada gambar 13 merupakan blok pemrograman untuk interface layar pengendali kunci kontak.

\section{Hasil dan Pembahasan}

Untuk menjalankan perangkat pengendali terdapat parameter yang akan diujikan, yaitu parameter jarak, throughput, RTT (round time trip). Pada sistem pengendali yang dibuat, digunakan sumber tegangan yang berasal dari accu yang terpasang pada sepeda motor yang rata-rata memiliki tegangan 12 volt.

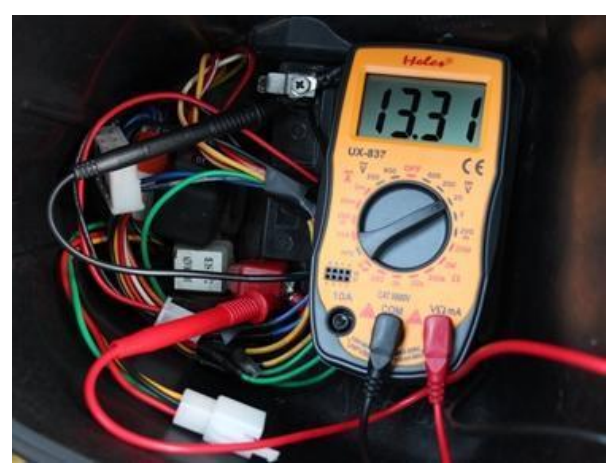

Gambar 14. Pengukuran Tegangan Catu Daya

Pada saat dilakukan pengukuran tegangan sumber, didapatkan tegangan dengan besar 13,31 volt seperti pada gambar 14 yang akan digunakan oleh rangkaian catu daya.

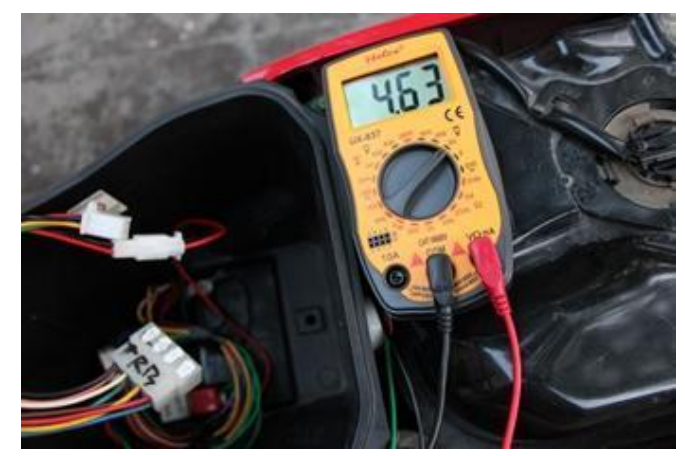

Gambar 15. Pengujian Tegangan IC Regulator LM7805

Tegangan yang digunakan sistem minimum NodeMCU dan relay 4 kanal adalah sebesar 5 volt, pada saat dilakukan pengukuran pada keluaran rangkaian catu daya pada kaki LM 7805 didapatkan tegangan sebesar 4,63 seperti pada gambar 15. Kemudian untuk menguji sistem keamanan, dengan menggunakan sensor SW420 untuk mendeteksi getaran yang diterima sepeda motor sebagai perintah menyalakan buzzer dapat berjalan dengan baik dan pada saat mencoba menyalakan motor dengan kunci manual, sepeda motor tidak dapat dinyalakan karena salah satu relay memutuskan kelistrikan sepeda motor aktif pada saat sistem keamanan dinyalakan.

Pengujian sistem interface pada perangkat android berupa sistem kerja rangkaian pengendali secara keseluruhan. Respon berupa sentuhan pada layar perangkat android untuk mengendalikan rangkaian sistem minimum NodeMCU dilakukan dengan memasukan perintah berikut ini. 
Tabel 1. Pengujian Layer Perintah Perangkat Android

\begin{tabular}{|c|c|c|}
\hline $\begin{array}{c}\text { Perinta } \\
\text { h }\end{array}$ & Alamat IP Kontrol & Status \\
\hline 1 & http://192.168.43.66/ITTPiot/keyon & Berhasil \\
\hline 2 & http://192.168.43.66/ITTPiot/starton & Berhasil \\
\hline 3 & $\mathrm{http}: / / 192.168 .43 .66 /$ ITTPiot/startoff & Berhasil \\
\hline 4 & $\mathrm{http}: / / 192.168 .43 .66 /$ ITTPiot/keyoff & Berhasil \\
\hline 5 & $\mathrm{http} / / / 192.168 .43 .66 /$ ITTPiot/safety & Berhasil \\
\hline 6 & $\mathrm{http} / / / 192.168 .43 .66 /$ ITTPiot/nosafety & Berhasil \\
\hline
\end{tabular}

Pada Tabel 1. menunjukan hasil pengujian sistem secara keseluruhan, pada saat mencoba menekan tombol on pada aplikasi yang digunakan untuk mengakses alamat internet protokol http://192.168.43.66/ITTPiot/keyon berhasil dan dapat menyalakan kunci kontak sepeda motor tanpa harus menggunakan kunci manual. Begitu pula dengan alamat ip kontrol yang lain yang digunakan untuk kontrol tombol starter on dan off, kunci kontak off dan pengaturan sistem keamanan yang dapat memutuskan sistem kelistrikan pada sepeda motor.

\section{B. Pengujian Konektifitas Menggunakan Wireshark}

Pengujian menggunakan wireshark bertujuan untuk mengetahui bagaimana kualitas jaringan yang dibentuk antara nodeMCU dengan hotspot yang digunakan untuk membentuk sebuah jaringan. Pengujian dilakukan dengan mengakses salah satu ip kontrol pada web browser pada komputer yang terhubung pada hotspot yang digunakan oleh nodeMCU.

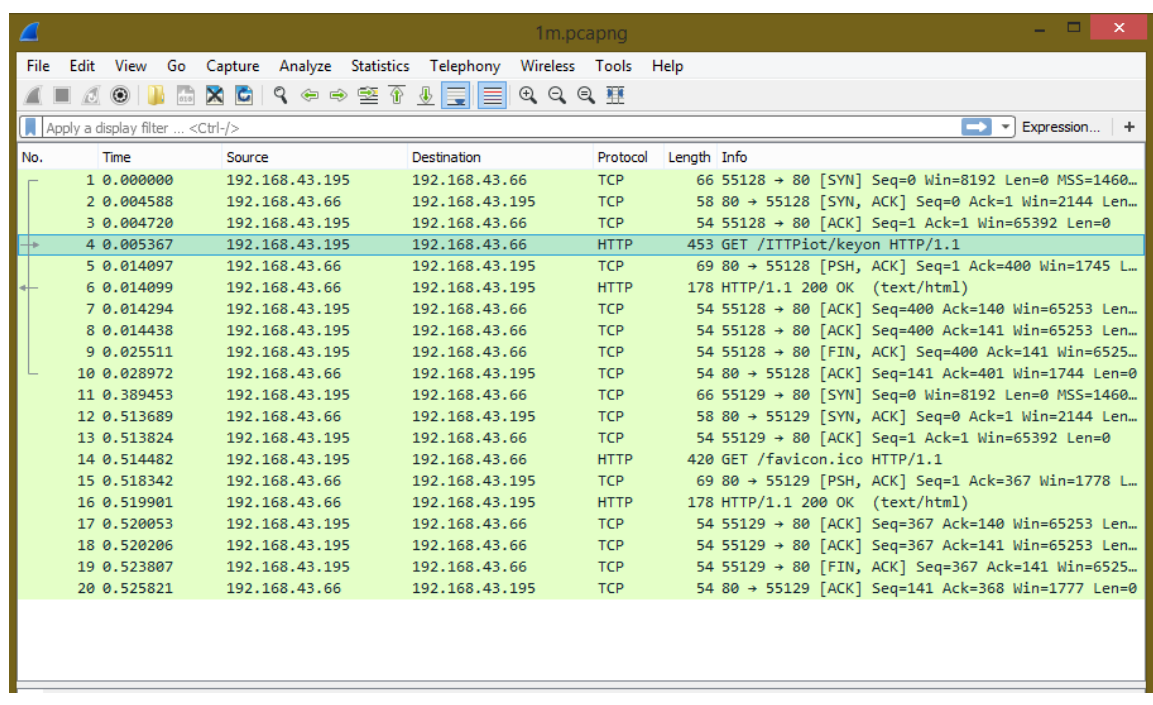

Gambar 16. Hasil Pengujian Wireshark

Setelah dilakukan pengujian, dihasilkan hasil seperti pada gambar 16 yang menunjukan ada 20 paket yang terbaca, namun paket yang berisi perintah kontrol berada pada paket nomor 4 dengan protokol HTTP dari ip milik komputer menuju ke alamat ip nodeMCU. 


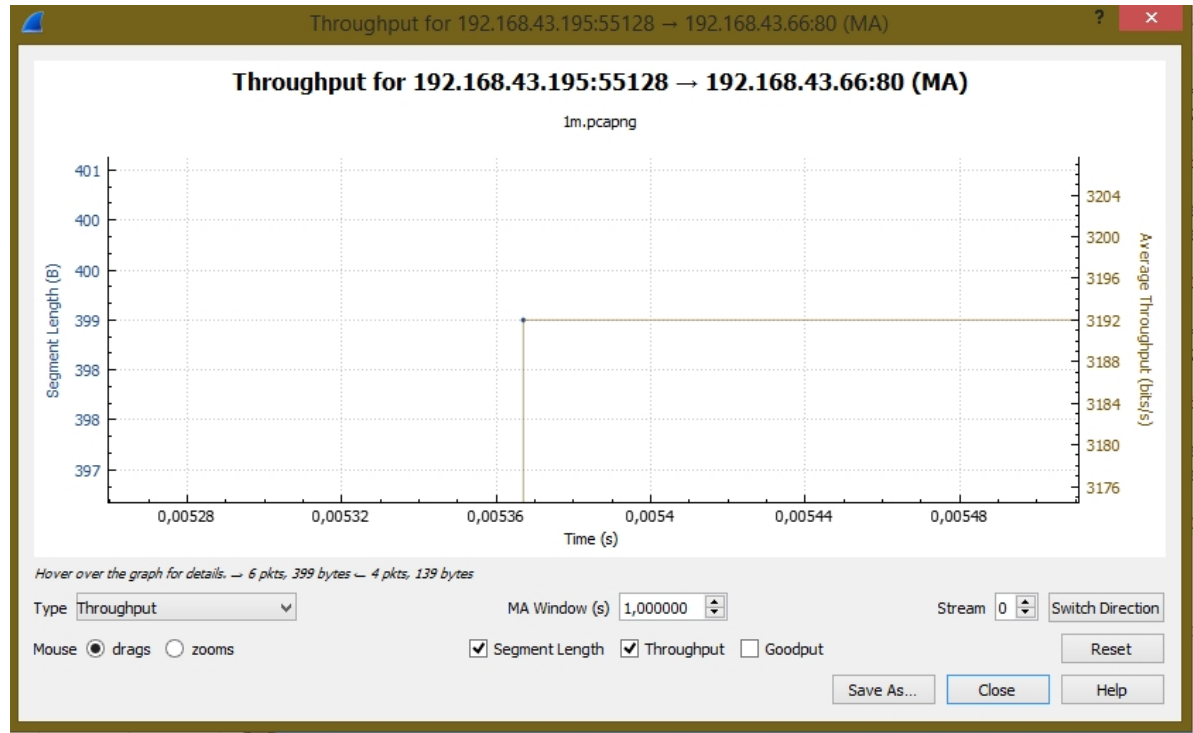

Gambar 17. Grafik Throughput

Jika nomor paket sudah diketahui maka, pada paket yang terbaca dapat dilakukan analisis throughput seperti pada gambar 17, yang mana pengujian ini dilakukan pada jarak 1 meter dari sepeda motor, yang didapatkan throughput sebesar 3192 bits/s dengan segment length 399 Byte.

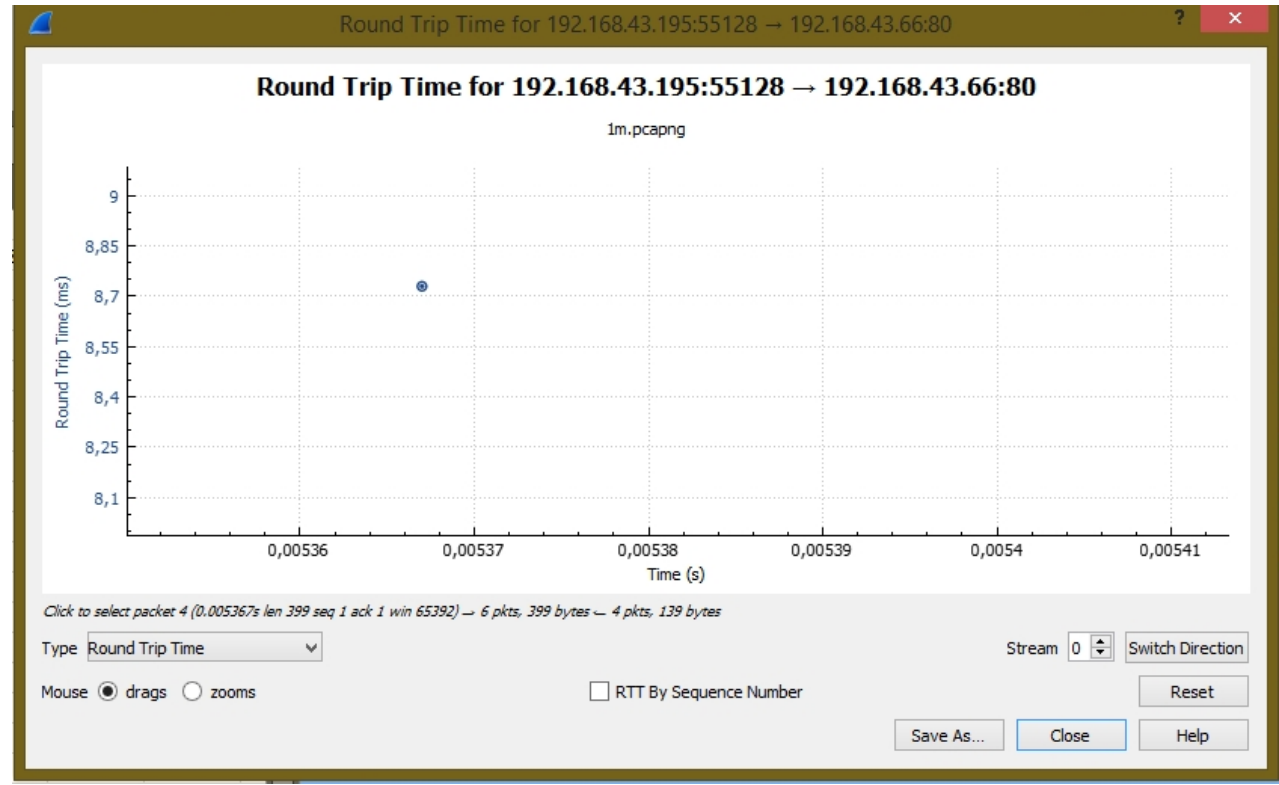

Gambar 18. Hasil Pengukuran RTT

Selain throughput juga dapat mengetahui waktu yang digunakan paket untuk melakukan perjalanan dari perangkat kontrol menuju nodeMCU dan kembali lagi ke perangkat kontrol atau round trip time (RTT) seperti pada gambar 18 .

Tabel 2. Pengujian Pengiriman Data

\begin{tabular}{|c|c|c|c|c|}
\hline $\begin{array}{c}\text { N } \\
\mathbf{o}\end{array}$ & $\begin{array}{c}\text { Jarak } \\
(\mathbf{m e t e r})\end{array}$ & $\begin{array}{c}\text { Throughpu } \\
\mathbf{t}(\mathbf{b i t s} / \mathbf{s})\end{array}$ & $\begin{array}{c}\text { RTT } \\
(\mathbf{m s})\end{array}$ & $\begin{array}{c}\text { Segment Length } \\
(\mathbf{B})\end{array}$ \\
\hline 1 & 1 & 3192 & 8,73 & 399 \\
\hline 2 & 2 & 3400 & 4 & 425 \\
\hline 3 & 4 & 3400 & 5,6 & 425 \\
\hline
\end{tabular}




\begin{tabular}{|c|c|c|c|c|}
\hline 4 & 6 & 3400 & 4,22 & 425 \\
\hline 5 & 8 & 3400 & 43,6 & 425 \\
\hline 6 & 10 & 3192 & 9 & 399 \\
\hline 7 & 12 & 3400 & 6,84 & 425 \\
\hline 8 & 14 & 3400 & 7,5 & 425 \\
\hline 9 & 16 & 3400 & 4,9 & 425 \\
\hline 10 & 18 & 3400 & 8,7 & 425 \\
\hline 11 & 20 & 3400 & 5,5 & 425 \\
\hline 12 & 22 & 3400 & 4,5 & 425 \\
\hline 13 & 24 & 3400 & 4,4 & 425 \\
\hline 14 & 26 & 3400 & 9,1 & 425 \\
\hline 15 & 28 & 3400 & 9,3 & 425 \\
\hline
\end{tabular}

Untuk tahap pengujian selanjutnya adalah melakukan kontrol dengan variasi jarak yang berbeda, seperti pada tabel 2, dimana pengukuran dimulai dengan jarak 1 meter yang memiliki besar throughput 3192 bits/s dengan RTT 8,73 ms dan segment length 399 B. Kemudian pada jarak 2 meter memiliki throughput 3400 bits/s dan segment length 425 B yang bertahan hingga jarak terjauh yaitu 30 meter dengan hasil RTT yang bervariasi, kecuali pada jarak 10 meter dimana throughput turun hingga 3192 bits/s dan segment length 399 B dengan RTT selama 9 ms.

\section{KESIMPULAN}

Dari hasil perancangan kemudian dilanjutkan dengan pengujian sistem keamanan dan kunci kontak sepeda motor yang telah dilakukan, didapatkan beberapa kesimpulan yaitu Pada saat dilakukan pengujian, secara keseluruhan sistem bekerja sesuai dengan rencana perancangan. Pada pengujian menggunakan wireshark, rata-rata memiliki throughput 3400 bits/s dengan segment length 435 Byte. Jarak pengendalian dapat dilakukan dengan jarak 28 meter dengan hasil ukur throughput dan RTT yang rata-rata. Saat sistem keamanan diaktifkan, sepeda motor tidak akan dapat dinyalakandenga kunci kontak manual, karena terputusnya kelistrikan sepeda motor karena salah satu relay aktif dan memutuskan jalur listrik motor. Sensor SW-420 dapat bekerja untuk menyalakan buzzer jika sistem keamanan diaktifkan dan mendapat repon getaran pada salah satu sensor yang digunaka

\section{REFERENCES}

[1] H. Safaat, Pemrograman Aplikasi MobileSmartphone dan Tablet PC Berbasis Android. Bandung: Informatika, 2014

[2] Immersa, "Pengertian Relay," 2018. [Online]. Available: http://www.immersa-lab.com/pengertian-relay-fungsi-dan-carakerja-relay.htm. [Accessed: 27-Jun-2018].

[3] T. T. Saputra, "Mengukur Pentingnya Heatsink Untuk Regulator Tegangan LM7805,” 2018.

[4] A. Najmurrokhman, B. H. S. R. Wibowo, U. Komarudin, and T. Pratama, "RANCANG BANGUN PROTOTIPE SISTEM INFORMASI KONDISI GEDUNG MENGGUNAKAN MIKROKONTROLER ARDUINO DAN MODUL GSM,” Pros. Semnastek, 2018.

[5] Zul, "Membuat Aplikasi Android Lebih Mudah Dengan Google App Inventor," 2014. [Online]. Available: https://www.codepolitan.com/membuat-aplikasi-android-lebih-mudah-dengan-google-app-inventor. [Accessed: 27-May2018].

[6] Sinararduino, "Mengenal Arduino Software Ide," $2016 . \quad$ [Online]. Available: https://www.sinauarduino.com/artikel/mengenal-arduino-software-ide/. [Accessed: 27-May-2018]. 